GRASAS Y ACEITES 72 (3)

July-September 2021, e421

ISSN-L: 0017-3495

https://doi.org/10.3989/gya.0449201

\title{
Selection criteria for yield in safflower (Charthamus tinctorius L.) genotypes under rainfed conditions
}

\author{
๑H. Koç $\bowtie$ \\ Bahri Dagdas International Agricultural Research Institute, Konya, Turkey \\ ${ }^{\bowtie}$ Correspondence: koc175@hotmail.com
}

Submitted: 21 April 2020; Accepted: 30 June 2020; Published online: 17 September 2021

SUMMARY: This research was conducted on 20 safflower genotypes and lasted 3 years (2014-2016) in the Central Anatolia Region of Turkey. The experiments were conducted in randomized block design with four replications. The relationships among yield 9 other traits in safflower genotypes were investigated. As the average of three years, the greatest seed yield (SY) was obtained from genotype G5 (PI 451952) with $3156.3 \mathrm{~kg} \cdot \mathrm{ha}^{-1}$. It was followed by genotypes G4 (PI 525458) and G9 (PI 306686) with $3013.2 \mathrm{and} 2977.1 \mathrm{~kg} \cdot \mathrm{ha}^{-1}$, respectively. Among the standard cultivars, the greatest seed yield $\left(2750.4 \mathrm{~kg} \cdot \mathrm{ha}^{-1}\right)$ was obtained from the Dinçer cultivar. The greatest oil content (OC) was obtained from the genotype G11 (PI 537665) with 36.5\%. It was followed by the genotypes G9 (PI 306686) (35.4\%), G6 (PI 537598) (35.4\%) and G14 (PI 560169) (35.3\%). Oil contents varied between 29.1-36.5\%. Yield-trait relationships were assessed through both correlation analysis and GT (Genotype by Trait) biplot analysis. Based on the results of the two approaches, plant height $(\mathrm{PH})$, number of branches $(\mathrm{NB})$, number of heads $(\mathrm{NH})$ and thousand-seed weight (TSW) were identified as the most significant selection criteria for yield from safflower. The combined use of correlation and biplot analysis in the assessment of relationships among the traits improved the chance for success.

KEY WORDS: Correlation; GT (Genotype by Trait)-biplot; Safflower; Selection; Yield

RESUMEN: Criterios de selección para el rendimiento en genotipos de cártamo (Charthamus tinctorius L.) en condiciones de secano. Esta investigación se realizó con 20 genotipos de cártamo durante 3 años (2014-2016) en la región de Anatolia central de Turquía. Los experimentos se realizaron en bloques de diseño aleatorio con cuatro repeticiones. Se investigaron las relaciones de rendimiento con los otros rasgos y las relaciones genotipo-rasgo en plantas de cártamo. Como promedio de tres años, el mayor rendimiento de semillas (SY) se obtuvo del genotipo G5 (PI 451952) con 3156,3 kg ha $^{-1}$. Le siguieron los genotipos G4 (PI 525458) y G9 (PI 306686) con 3013,2 y $2977,1 \mathrm{~kg} \cdot \mathrm{ha}^{-1}$ respectivamente. Entre los cultivares estándar, el mayor rendimiento de semilla $\left(2750,4 \mathrm{~kg} \cdot \mathrm{ha}^{-1}\right)$ se obtuvo del cultivar Dinçer. El mayor contenido de aceite (OC) se obtuvo del genotipo G11 (PI 537665) con 36,5\%. El contenido de aceite varió entre 29,1 - 36,5\%. Las relaciones rendimiento-rasgo se evaluaron mediante análisis de correlación y análisis biplot GT (Genotipo por rasgo). Con base en los resultados de dos enfoques, la altura de la planta $(\mathrm{PH})$, el número de ramas $(\mathrm{NB})$, el número de cabezas $(\mathrm{NH})$ y el peso de miles de semillas (TSW) se identificaron como los criterios de selección más importantes para el rendimiento en el cártamo. El uso combinado de análisis de correlación y biplot en la evaluación de las relaciones entre los rasgos mejoró la posibilidad de éxito.

PALABRAS CLAVE: Cártamo; Correlación; GT (genotipo por rasgo)-biplot; Rendimiento; Selección

Citation/Cómo citar este artículo: Koç H. 2021. Selection criteria for yield in safflower (Charthamus tinctorius L.) genotypes under rainfed conditions. Grasas Aceites 72 (3), e421. https://doi.org/10.3989/gya.0449201

Copyright: $(2021$ CSIC. This is an open-access article distributed under the terms of the Creative Commons Attribution 4.0 International (CC BY 4.0) License. 


\section{INTRODUCTION}

Safflower (Charthamus tinctorius L.) requires less water than other oil crops such as rapeseed (Brassica napus ssp. oleifera L.), sunflower (Helianthus annuus L.) and soybean (Glycine $\max$ L. Merr.) and it is quite well adapted to dry conditions. Thus, it had become a salient crop in the midst of present climate change and global warming trends. Safflower is an important oil crop both for cooking oil and biodiesel production. High drought resistance provides significant advantages to safflower over other oil crops in cropping patterns (Kose, 2017).

Low yield and decreased percentage are the basic limitation in safflower production. Therefore, plant improvement studies mostly focused on the development of new safflower lines with high seed yield and more oil content so as to meet the demands of growers and the industry (Koç et al., 2010).

Success of a breeding program is directly related to the proper selection of yield components at every stage of the program, efficient interpretation and use of resultant data (Flores et al., 1998; Rubio et al., 2004; Baljani et al., 2015).

In breeding programs for high yield cultivars, the assessment of yield and highly-heritable characteristics may improve the chance for success. Therefore, while generating breeding programs, it is useful to know the relationships among the characteristics. The ultimate target in safflower breeding is to develop new and superior cultivars with high seed yield and oil content. Breeders search for reliable selection criteria and then select the characteristics which are directly or indirectly related to yield. Especially in the early stages (F2-F5) with insufficient seed quantity for yield experiments, yield-related parameters play an important role.

Genotype selection brings a new dimension to the complexity and difficulty of plant breeding programs. Multiple breeding targets should be taken into consideration when selecting genotypes and recommending cultivars. In fact, plant breeding not only improves the yield of a plant, but also integrates high yield with the desired parameters like quality and performance (Yan et al., 2019a).

Despite reasonable values for the other parameters, genotypes with a value for a certain trait below the minimum requirements are hard to register. For instance, high quality is a valuable trait only when it is related to high yield; a high-quality genotype with a low yield will not be registered as a cultivar. Therefore, it is quite significant to take entire key traits into consideration when selecting genotypes and/or agronomic methods (Yan et al., 2019b).

The genotype - trait (GT) biplot procedure of GGE biplot method is used to assess the different traits of the genotypes. GT biplot allows the user to make visual assessments of genotype-trait data. Compared to conventional methods, the GT biplot approach has some advantages: 1 . Graphical presentation of the data improves comprehension of data patterns; 2 . It is easy to interpret, facilitate the comparison of genotypes or traits and efficiently presents the relationships among the investigated traits; 3 . It is easy to see which genotype is winning or losing in which trait; 4. It can be used in multi-trait-based selections and in the comparison of selection strategies (Yan et al., 2007). While correlation analysis identifies the level of relationship between the traits, the GT biplot is able to put forth both the relationships among the traits and genotype - trait relationships (Yan and Reid, 2008).

In this study, the GT (Genotype by Trait) biplot technique and correlation analysis were used together to investigate the Genotype-Trait relationships and the relations among the traits.

The aim of this study is for the findings to be useful for safflower breeders and safflower producers who are concerned with increasing seed yield with the data obtained.

\section{MATERIALS AND METHODS}

This research was carried out with 20 genotypes (Table 1) over 3 years (2014-2016) in the Central Anatolia Region of Turkey. The experiments were conducted in randomized block design with 4 replications. The plot size was $6 \mathrm{~m}^{2}(1.2 \times 5 \mathrm{~m})$ and seeds were sown with an experimental sowing machine. Sowing was performed in the last week of March so as to have 125 seed per $\mathrm{m}^{2}$. Harvest was carried out in the second week of August with a plot combine harvester.

The experimental soils were of a clay texture with a moderate organic material level $(2.3 \%)$ and high lime content $(29 \%)$. The soils were slightly alkaline $(\mathrm{pH} 7.8)$, rich in phosphorus and potassium and deficient in zinc. There were no salinity problems at the research site.

Monthly average temperatures during the experimental years were close to long-term averages 
TABLE 1. Name and origin of the studied safflower genotypes

\begin{tabular}{ccccc}
\hline Entry & Genotip & Code & Accession number & Origin \\
\hline 1 & $28-2$ & G1 & PI 537110 & Mexico \\
2 & $11-1$ & G2 & PI 560172 & United States \\
3 & $77-2-\mathrm{a}$ & G3 & PI 537606 & United States \\
4 & $82-3$ & G4 & PI 525458 & United States \\
5 & $25-4-b$ & G5 & PI 451952 & India \\
6 & $106-2$ & G6 & PI 537598 & United States \\
7 & Göktürk & Göktürk & BDYAS-4 & Turkey \\
8 & $63-2-b$ & G7 & PI 537702 & United States \\
9 & Dinçer & Dinçer & GKTAE & Turkey \\
10 & $64-3-b$ & G8 & PI 537703 & United States \\
11 & $91-2$ & G9 & PI 306686 & Israel \\
12 & Linas & Linas & TTAE & Turkey \\
13 & Balc1 & Balc1 & EGKTAE & Turkey \\
14 & $77-1-d$ & G10 & PI 537607 & United States \\
15 & $89-1-c$ & G11 & PI 537665 & United States \\
16 & $13-2-c$ & G12 & PI 537607 & United States \\
17 & $96-3$ & G13 & PI 544059 & China \\
18 & $56-2-c$ & G14 & PI 560169 & United States \\
19 & $52-1$ & G15 & PI 307056 & Mexico \\
20 & $83-1-a$ & G16 & PI 537694 & United States \\
\hline & & & &
\end{tabular}

(Table 2). On the other hand, total temperatures throughout the vegetation period (March - August) were $5.8^{\circ} \mathrm{C}$ greater in 2014 and 2016 than the longterm averages $\left(104.8^{\circ} \mathrm{C}\right)$.

Total precipitation was measured as $366 \mathrm{~mm}$ in 2014 (44 $\mathrm{mm}$ greater than the long-term average), as $309 \mathrm{~mm}$ in 2015 (close to long-term average of 322 $\mathrm{mm})$ and as $201 \mathrm{~mm}$ in 2016 (121 $\mathrm{mm}$ lower than long-term average) (Table 2).

Observations and measurements: Seed yield $\left(\mathrm{kg} \cdot \mathrm{ha}^{-1}\right)$, oil content $(\%)$, oil yield, plant height $(\mathrm{cm})$, number of days to $50 \%$ flowering, number of branches, number of heads, head diameter $(\mathrm{cm})$, thousand-seed weight (g).

Variance analyses were run on the data obtained from 20 safflower genotypes. A linear correlation analysis was applied pairwise to all the parameters studied, yield (SY) and other traits (OC, OY, PH, NDF, NB, NH, HD, and TSW). The experimental data were subjected to variance and correlation analyses with the aid of JMP 5.0 software. Significant means were compared with the aid of the LSD test. A GT biplot analysis for the visual assessment of Genotype - Trait relationships and the relationships among the traits was conducted with the use of XLSTAT software. The GT biplot analysis was employed to display the two-way relationship between genotype and trait. It was based on the following formula:

$\frac{T i j-\beta j}{S j}=\sum_{n=1}^{2} \lambda n \xi i n \eta j n+\varepsilon i j=\sum_{n=1}^{2} \xi * i n \eta * j n+\varepsilon i j$

where $T_{i j}$ is the average value for genotype $i$ for trait $\mathrm{j} ; \beta_{\mathrm{j}}$ is the average value for all genotypes in trait $j ; S_{j}$ is the standard deviation of trait $j$ among the genotype averages; $\lambda_{n}$ is the singular value for principal component $\mathrm{PC}_{\mathrm{n}} ; \xi_{\text {in }}$ and $\eta_{\mathrm{jn}}$ are scores for genotype $\mathrm{I}$ and trait $\mathrm{j}$ on $\mathrm{PC}_{\mathrm{n}}$, respectively; and $\epsilon_{\mathrm{ij}}$ is the residual associated with genotype $i$ in trait $j$. To achieve symmetric scaling between the genotype

TABLE 2. Monthly precipitation ( $\mathrm{mm}$ ) and monthly temperature averages (C0) for years and during years (1929-2016) of the experiment

\begin{tabular}{lllllllllllllll}
\hline & \multicolumn{10}{c}{} & \multicolumn{10}{c}{ Months } \\
\hline \multirow{4}{*}{ Prep. } & Years & Jan. & Feb. & Mar & Apr & May & June & July & Aug. & Sept & Oct & Nov. & Dec. & TOT \\
& $\mathbf{2 0 1 4}$ & 58.8 & 17.4 & 20.4 & 19.2 & 26 & 31.4 & 3 & 4.6 & 31.4 & 89.6 & 32.2 & 32.1 & 366 \\
& $\mathbf{2 0 1 5}$ & 24.6 & 23.5 & 55.9 & 7.6 & 53.2 & 39.6 & 8.6 & 17.2 & 31.4 & 39.0 & 5.8 & 2.6 & 309 \\
& $\mathbf{2 0 1 6}$ & 42.4 & 2.8 & 37.8 & 9.4 & 35.2 & 18.4 & 0.2 & 0.0 & 23 & 0.0 & 16.0 & 16.4 & 201 \\
& Long years & 38 & 29 & 28 & 32 & 43 & 24 & 6 & 5 & 13 & 30 & 32 & 42 & 322 \\
\hline \multirow{3}{*}{ Temp. } & $\mathbf{2 0 1 4}$ & 2.4 & 6.4 & 7.2 & 12.3 & 15.5 & 19.7 & 25.1 & 25.0 & 22.6 & 15.8 & 5.8 & 5.5 & 163 \\
& $\mathbf{2 0 1 5}$ & 0.7 & 4.8 & 5.9 & 8.1 & 15.7 & 18.7 & 24.0 & 24.6 & 21.8 & 14.6 & 7.9 & -0.8 & 146 \\
& $\mathbf{2 0 1 6}$ & 0.1 & 6.8 & 7.7 & 14.5 & 15.9 & 22.2 & 24.9 & 19.6 & 17.9 & 12.8 & 7 & 2 & 151 \\
& Long years & -0.3 & 1 & 5.7 & 11 & 15.8 & 20.4 & 23.6 & 23.2 & 18.7 & 12.6 & 5.9 & 1.5 & 139 \\
\hline
\end{tabular}

TOT: Total, Prep: Precipitation, Temp: Temperature 
scores and the trait scores the singular value $\lambda_{n}$ had to be absorbed by the singular vector for genotypes $\xi_{\text {in }}$ and that for traits $\eta_{\text {jn. }}$. That is, $\xi^{\text {in }}=\lambda^{\text {n. } 5} \xi_{\text {in }}$ and $\eta^{\text {jn }}$ $=\lambda^{\mathrm{n} .5} \eta_{\mathrm{jn}}$. Only PC1 and PC2 were retained in the model because such a model tends to be the best for extracting pattern and rejecting noise from the data. The GT biplot was generated by plotting $\xi^{i 1}$ and $\xi^{\mathrm{i} 2}$ against $\eta^{\mathrm{j} 1}$ and $\eta^{\mathrm{j} 2}$, respectively, so that each genotype or trait was represented by a marker in the biplot. In the GT biplot, a vector was drawn from the biplot origin to each marker of the traits to facilitate visualization of the relationships between and among the traits (Yan and Rajcan, 2002; Akçura, 2011).

\section{RESULTS AND DISCUSSION}

The variance analysis revealed that there were significant differences among all the traits of the genotypes $(\mathrm{P}<0.01)$. Year $\mathrm{x}$ genotype interaction was also found to be significant for all traits, except for head diameter (HD) (Table 3).

For the average of the three years, genotype G5 had the greatest seed yield (SY) with $3156.3 \mathrm{~kg} \cdot \mathrm{ha}^{-1}$. It was followed by genotypes G4 and G9 (with 3013.2 and $2977.1 \mathrm{~kg} \cdot \mathrm{ha}^{-1}$ ) (Table 4). Among the standard cultivars, the greatest seed yield $\left(2750.4 \mathrm{~kg} \cdot \mathrm{ha}^{-1}\right)$ was obtained from the Dinçer cultivar. The greatest oil content (36.5\%) was observed in genotype G11 and it was followed by genotypes G9 (35.4\%), G6 $(35.4 \%)$ and G14 (35.3\%). The oil contents in the genotypes varied from $29.1-36.5 \%$. The oil yield (OY) values, calculated by multiplying seed yield by oil content, varied from $717.9-1058.6 \mathrm{~kg} \cdot \mathrm{ha}^{-1}$.

Plant height $(\mathrm{PH})$ values varied from 67.8 - 81.5 $\mathrm{cm}$. Ideal safflower plant heights for machine harvest should be between $60-80 \mathrm{~cm}$ (Weiss, 2000). All the present genotypes yielded plant heights within this range. The number of days to flowering (NDF) values varied from 68 - 76 days; the number of branches

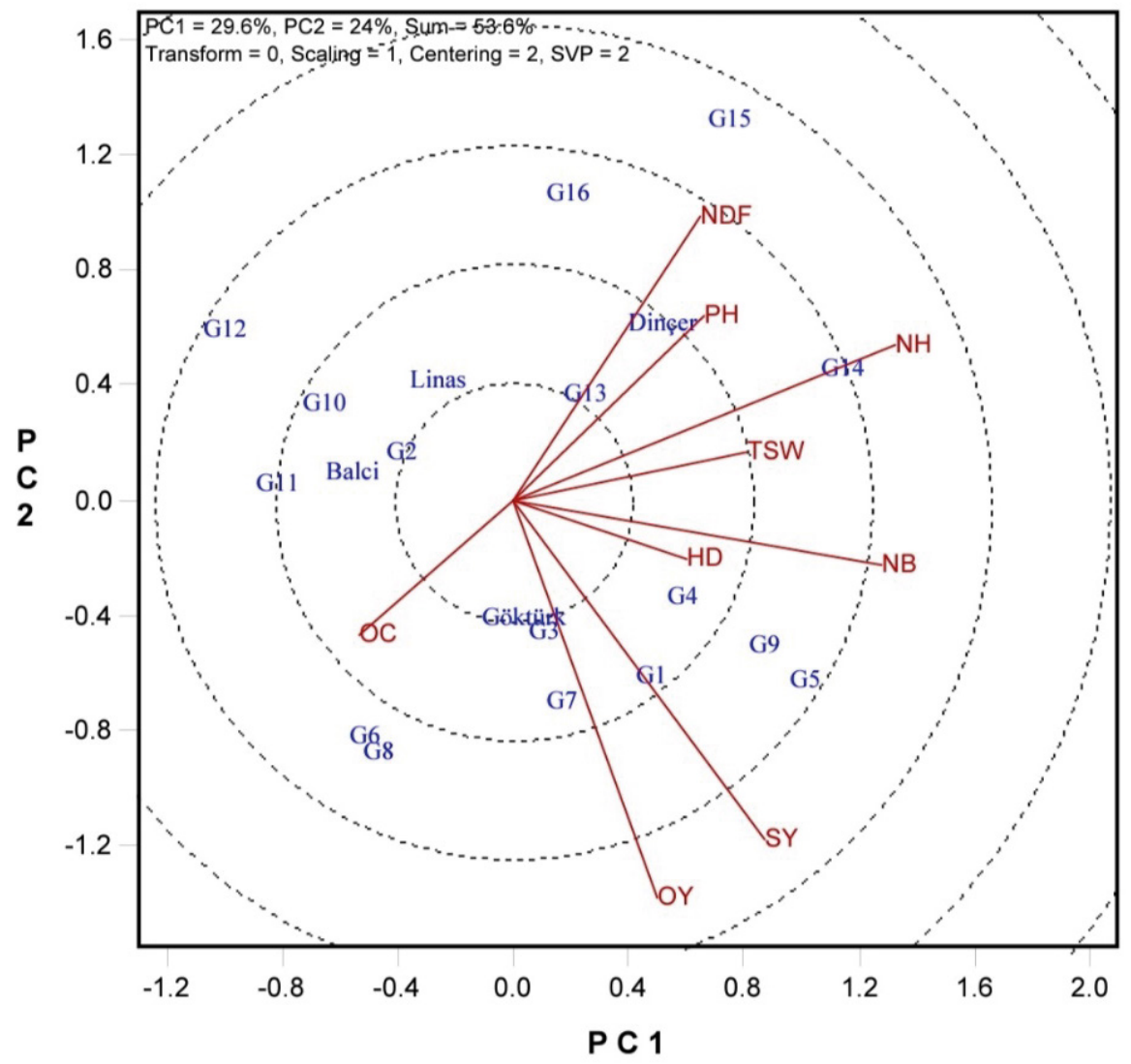

FIGURE 1. Vector view of genotype by trait biplot, showing the interrelationship among all measured traits for 20 different safflower genotypes. Traits: SY: Seed Yield, OC: Oil Content, OY: Oil Yield, PH: Plant Height, NDF: Number of Days to \%50 Flowering, NB: Number of Branches, NH: Number of Heads, HD: Head Diameter, TSW: Thousand-Seed Weight 
Selection criteria for yield in safflower (Charthamus tinctorius L.) genotypes under rainfed conditions $\bullet 5$

TABLE 3. Analysis of the combined variance of the properties studied

\begin{tabular}{lcccccccccc}
\hline \multicolumn{1}{c}{ SV } & DF & SY & OC & OY & PH & NDF & NB & NH & HD & TSW \\
\hline & & MS & MS & MS & MS & MS & MS & MS & MS & MS \\
\hline Replication & 3 & $3541^{* *}$ & 0.9 & $383^{* *}$ & 98 & $4.6^{*}$ & 0.7 & $3^{*}$ & 0.06 & 0.3 \\
Year & 2 & $278845^{* *}$ & $43^{* *}$ & $30859^{* *}$ & $10194^{* *}$ & $3222^{* *}$ & $18^{* *}$ & $89^{* *}$ & 0.01 & $81^{* *}$ \\
Genotyp & 19 & $7674^{* *}$ & $42^{* *}$ & $1021^{* *}$ & $138^{* *}$ & $48^{* *}$ & $7.4^{* *}$ & $13^{* *}$ & $0.06^{*}$ & $58^{* *}$ \\
Year x Genotyp & 38 & $6179^{* *}$ & $9^{* *}$ & $870^{* *}$ & $97^{* *}$ & $34^{* *}$ & $1.2^{*}$ & $5.8^{* *}$ & 0.04 & $30^{* *}$ \\
Error & 177 & 575 & 0.4 & 65 & 38 & 1.6 & 0.7 & 1.0 & 0.04 & 0.8 \\
Total & 239 & $4396^{* *}$ & $5.5^{* *}$ & $530^{* *}$ & $141^{* *}$ & $37^{* *}$ & $1.5^{* *}$ & $3.4^{* *}$ & 0.04 & $11^{* *}$ \\
\hline
\end{tabular}

SV: Source of Variance, DF: Degrees of Freedom, MS: Mean Square, ${ }^{* *} \mathrm{P}<0.01$ significant, $* \mathrm{P}<0.05$ significant

SY: Seed Yield, OC: Oil Content, OY: Oil Yield, PH: Plant Height, NDF: Number of Days to \%50 Flowering, NB: Number of Branches,

NH: Number of Heads, HD: Head Diameter, TSW: Thousand Seed Weight(g)

TABLE 4. Mean yield and yield components (4 replications) of 20 safflower genotypes tested over 3 (2014-2016) years

\begin{tabular}{|c|c|c|c|c|c|c|c|c|c|}
\hline Code & SY & OC & OY & PH & NDF & NB & NH & HD & TSW \\
\hline G5 & $3156.3 \mathrm{a}$ & $32.34 \mathrm{~g}$ & $1024.2 \mathrm{ab}$ & $76.9 \mathrm{abc}$ & $71.3 \mathrm{fg}$ & $6.2 \mathrm{ab}$ & $6.7 \mathrm{bc}$ & $2.30 \mathrm{a}-\mathrm{d}$ & $41.5 \mathrm{def}$ \\
\hline G4 & $3013.2 \mathrm{ab}$ & 32.89 ef & $978.7 \mathrm{bcd}$ & $76.4 \mathrm{bcd}$ & $73.0 \mathrm{cde}$ & $5.5 \mathrm{bcd}$ & $6.0 \mathrm{cde}$ & $2.35 \mathrm{ab}$ & $39.1 \mathrm{k}$ \\
\hline G9 & $2977.1 \mathrm{abc}$ & $35.46 \mathrm{~b}$ & $1058.6 \mathrm{a}$ & $77.2 \mathrm{abc}$ & $72.5 \mathrm{cde}$ & $6.4 \mathrm{a}$ & $6.6 \mathrm{bc}$ & $2.25 \mathrm{a}-\mathrm{d}$ & $41.2 \mathrm{fg}$ \\
\hline G7 & $2975.4 \mathrm{abc}$ & $32.05 \mathrm{~g}$ & $947.0 \mathrm{cde}$ & $69.9 \mathrm{fg}$ & $70.7 \mathrm{~g}$ & $5.2 \mathrm{cde}$ & $5.6 \mathrm{def}$ & $2.37 \mathrm{a}$ & $40.2 \mathrm{~h} 1$ \\
\hline G3 & $2955.2 \mathrm{bc}$ & 32.91 ef & $968.9 \mathrm{bcd}$ & $71.5 \mathrm{~d}-\mathrm{g}$ & $71.4 \mathrm{fg}$ & $5.0 \mathrm{def}$ & $5.9 \mathrm{~cd}$ & $2.17 \mathrm{~d}$ & $42.1 \mathrm{cde}$ \\
\hline G1 & $2892.9 \mathrm{bcd}$ & $33.24 \mathrm{de}$ & $967.3 \mathrm{bcd}$ & $73.8 \mathrm{~b}-\mathrm{f}$ & $69.5 \mathrm{~h}$ & $5.5 \mathrm{bcd}$ & $6.0 \mathrm{cde}$ & $2.33 \mathrm{abc}$ & $43.7 \mathrm{~b}$ \\
\hline G8 & $2854.1 \mathrm{bcd}$ & $33.68 \mathrm{~cd}$ & $967.6 \mathrm{bcd}$ & $67.8 \mathrm{~g}$ & $69.2 \mathrm{~h}$ & $4.7 \mathrm{efg}$ & $4.9 \mathrm{fg}$ & $2.26 \mathrm{a}-\mathrm{d}$ & $40.0 \mathrm{hij}$ \\
\hline G6 & 2819.5 cde & $35.45 \mathrm{~b}$ & $1009 \mathrm{abc}$ & $70.2 \mathrm{efg}$ & $69.2 \mathrm{~h}$ & $4.3 \mathrm{fgh}$ & $5.0 \mathrm{fg}$ & $2.18 \mathrm{~cd}$ & $42.3 \mathrm{~cd}$ \\
\hline Dinçer & $2750.4 \mathrm{def}$ & $29.11 \mathrm{~h}$ & $803.6 \mathrm{ij}$ & $78.4 \mathrm{ab}$ & $71.4 \mathrm{fg}$ & $5.8 \mathrm{abc}$ & $6.3 \mathrm{bcd}$ & $2.16 \mathrm{~d}$ & $41.3 \mathrm{fg}$ \\
\hline G2 & $2640.9 \mathrm{efg}$ & $32.08 \mathrm{~g}$ & $849.5 \mathrm{ghi}$ & $71.7 \mathrm{~d}-\mathrm{g}$ & $73.2 \mathrm{bcd}$ & $4.4 \mathrm{fgh}$ & $4.9 \mathrm{fg}$ & $2.35 \mathrm{ab}$ & $37.5 \mathrm{~m}$ \\
\hline Göktürk & $2635.7 \mathrm{e}-\mathrm{h}$ & $34.19 \mathrm{c}$ & $897.1 \mathrm{efg}$ & $71.6 \mathrm{~d}-\mathrm{g}$ & $68 \mathrm{~h} 1$ & $6.4 \mathrm{a}$ & $6.1 \mathrm{cde}$ & $2.18 \mathrm{~cd}$ & $39.81 \mathrm{jk}$ \\
\hline G14 & $2634.7 \mathrm{e}-\mathrm{h}$ & $35.33 \mathrm{~b}$ & $935.2 \mathrm{def}$ & $78.4 \mathrm{ab}$ & $74.0 \mathrm{~b}$ & $5.7 \mathrm{a}-\mathrm{d}$ & $8.5 \mathrm{a}$ & $2.37 \mathrm{a}$ & $42.7 \mathrm{c}$ \\
\hline G13 & $2582.7 \mathrm{f}-1$ & $33.23 \mathrm{de}$ & 858.1 gh1 & $75.4 \mathrm{bcd}$ & $72.0 \mathrm{ef}$ & $4.6 \mathrm{efg}$ & $5.8 \mathrm{cde}$ & $2.32 \mathrm{a}-\mathrm{d}$ & $45.5 \mathrm{a}$ \\
\hline Linas & $2557.6 \mathrm{f}-1$ & $35.02 \mathrm{~b}$ & $895.5 \mathrm{efg}$ & $81.5 \mathrm{a}$ & $72.5 \mathrm{de}$ & $4.1 \mathrm{gh}$ & $5.3 \mathrm{efg}$ & $2.19 \mathrm{bcd}$ & $40.6 \mathrm{gh}$ \\
\hline Balc1 & $2497.4 \mathrm{~g}-\mathrm{j}$ & $35.00 \mathrm{~b}$ & $873.2 \mathrm{fgh}$ & $72.5 \mathrm{e}-\mathrm{g}$ & $71.3 \mathrm{fg}$ & $4.7 \mathrm{efg}$ & $5.3 \mathrm{efg}$ & $2.16 \mathrm{~d}$ & $39.9 \mathrm{hij}$ \\
\hline G10 & 2442.7 h-k & $33.39 \mathrm{de}$ & $816.5 \mathrm{hij}$ & $74.3 \mathrm{~b}-\mathrm{f}$ & $70.5 \mathrm{~g}$ & $4.2 \mathrm{gh}$ & $4.8 \mathrm{fg}$ & $2.20 \mathrm{bcd}$ & $41.7 \mathrm{def}$ \\
\hline G15 & $2421.61-\mathrm{k}$ & $29.51 \mathrm{~h}$ & $717.9 \mathrm{k}$ & $73.0 \mathrm{c}-\mathrm{f}$ & $73.5 \mathrm{bc}$ & $6.0 \mathrm{ab}$ & $7.9 \mathrm{a}$ & $2.18 \mathrm{~cd}$ & $45.2 \mathrm{a}$ \\
\hline G16 & $2401.11-\mathrm{k}$ & $32.48 \mathrm{fg}$ & $779.1 \mathrm{jk}$ & $73.8 \mathrm{~b}-\mathrm{f}$ & $76.2 \mathrm{a}$ & $5.0 \mathrm{def}$ & $6.9 \mathrm{~b}$ & $2.31 \mathrm{a}-\mathrm{d}$ & $39.3 \mathrm{jk}$ \\
\hline G11 & $2336.0 \mathrm{jk}$ & $36.46 \mathrm{a}$ & $853.4 \mathrm{gh} 1$ & $71.8 \mathrm{~d}-\mathrm{g}$ & $68.9 \mathrm{~h}_{1}$ & $4.7 \mathrm{efg}$ & $5.5 \mathrm{def}$ & $2.23 \mathrm{a}-\mathrm{d}$ & $37.7 \mathrm{~lm}$ \\
\hline G12 & $2297.6 \mathrm{k}$ & $33.67 \mathrm{c}$ & $779.3 \mathrm{jk}$ & $75.2 \mathrm{~b}-\mathrm{e}$ & $71.1 \mathrm{fg}$ & $3.8 \mathrm{~h}$ & $4.5 \mathrm{~g}$ & $2.24 \mathrm{a}-\mathrm{d}$ & 38.21 \\
\hline LSD (\%5) & 187.2 & 0.51 & 64.9 & 4.9 & 1.0 & 0.3 & 0.8 & 0.15 & 0.7 \\
\hline CV (\%) & 8.5 & 1.8 & 8.7 & 8.0 & 1.8 & 15 & 16 & 8 & 2.2 \\
\hline
\end{tabular}

SY: Seed Yield $\left(\mathrm{kg} \cdot \mathrm{ha}^{-1}\right)$, OC: Oil Content (\%), OY: Oil Yield $\left(\mathrm{kg} \cdot \mathrm{ha}^{-1}\right)$, PH: Plant Height (cm), NDF: Number of Days to \%50 Flowering, NB: Number of Branches, NH: Number of Heads, HD: Head Diameter (cm), TSW: Thousand-Seed Weight (g) 
TABLE 5. Correlation coefficients among characteristics of safflower genotypes

\begin{tabular}{|c|c|c|c|c|c|c|c|c|c|}
\hline & SY & OC & OY & PH & NDF & NB & NH & HD & TSW \\
\hline SY & 1.00 & & & & & & & & \\
\hline OC & $0.03 \mathrm{NS}$ & 1.00 & & & & & & & \\
\hline OY & $0.96^{* *}$ & $0.30 * *$ & 1.00 & & & & & & \\
\hline PH & $0.56^{* *}$ & $-0.07 \mathrm{NS}$ & $0.51 * *$ & 1.00 & & & & & \\
\hline NDF & $0.15^{*}$ & $0.13^{*}$ & $0.17 * *$ & $0.009 \mathrm{NS}$ & 1.00 & & & & \\
\hline NB & $0.16^{*}$ & $-0.20 * *$ & $0.09 \mathrm{NS}$ & $0.24 * *$ & $-0.16^{*}$ & 1.00 & & & \\
\hline NH & $0.44 * *$ & $-0.05 \mathrm{NS}$ & $0.40 * *$ & $0.47 * *$ & $0.34 * *$ & $0.48 * *$ & 1.00 & & \\
\hline HD & $0.06 \mathrm{NS}$ & $0.002 \mathrm{NS}$ & $0.06 \mathrm{NS}$ & $0.14^{*}$ & $0.02 \mathrm{NS}$ & $0.13^{*}$ & $0.20 * *$ & 1.00 & \\
\hline TSW & $0.18^{* *}$ & $-0.08 \mathrm{NS}$ & $0.15 *$ & $0.04 \mathrm{NS}$ & $0.19 * *$ & $0.07 \mathrm{NS}$ & $0.26^{* *}$ & $0.09 \mathrm{NS}$ & 1.00 \\
\hline
\end{tabular}

**Significant at $\mathrm{P}<0.01, *$ Significant at $\mathrm{P}<0.05$ and NS: not significant.

SY: Seed Yield, OC: Oil Content, OY: Oil Yield, PH: Plant Height, NDF: Number of Days to 50\% Flowering, NB: Number of Branches, NH: Number of Heads, HD: Head Diameter, TSW: Thousand-Seed Weight.

(NB) varied from 3.8 - 6.4; the number of heads per plant $(\mathrm{NH})$ varied from $4.5-8.5$; head diameters (HD) varied from $2.16-2.37 \mathrm{~cm}$; and thousand-seed weights (TSW) varied from $37.5-45.5 \mathrm{~g}$.

Correlation coefficients among the investigated traits are provided in Table 5 and the genotype - trait (GT) biplot graph is presented in Figure 1.

Seed yield (SY) showed significant positive correlations with oil yield (OY), plant height $(\mathrm{PH})$, number of days to flowering (NDF), number of branches (NB), number of heads (NH) and thousandseed weight (TSW). Seed yield (SY) had insignificant correlations with oil content (OC) and head diameter (HD).

Safflower breeding programs are implemented to obtain seed yield components, to determine the relationships among these components and to identify proper selection criteria. Similar to the present study, Mozaffari and Asadi (2006), Camas et al. (2007), Hussein et al. (2018) and Ali et al. (2020) reported the number of heads per plant as the most significant yield component and indicated significant correlations between seed yield and number of heads per plant.

Koç et al. (2010) conducted studies on safflower genotypes and reported significant positive correlations between number of days to flowering and seed yield. In the present study, a significant positive correlation $\left(\mathrm{r}=0.15^{*}\right)$ was observed between seed yield and number of days to flowering at the $5 \%$ level (Table 5). The lower level of significance in the present study compared to previous studies was mainly attributed to the effects of environmental factors on the number of days to flowering. Especially under water stress conditions, plants pass into the generative stage faster. The levels of relationships between seed yield and number of days to flowering is higher and positive under normal climate conditions, but weaker under stress conditions. Plant height is also used as a selection criterion for safflower. Alizadeh (2005), Arslan (2007), Coşge and Kaya (2008), Nabloussi et al. (2008), Eslam et al. (2010) and Koç et al. (2010) conducted research on safflower genotypes and reported significant positive correlations between seed yield and plant height. Similar to those studies, a significant positive correlation $\left(\mathrm{r}=0.56^{* *}\right)$ was observed between seed yield and plant height in this study (Table 5).

Branching is an important parameter for the number of heads per plant. Thus, the number of branches increases seed yield. Similar to the present study, Camas et al. (2007), Golkar et al. (2012), Ali et al. (2020) also reported significant positive correlations between seed yield and number of branches.

Head diameter is an important morphological trait of safflower. However, the correlations between seed yield and head diameter were not found to be significant $(\mathrm{r}=0.06)$ (Table 5). Akbar and Kamran (2006), Baljani et al. (2015), Hussein et al. (2018) and Ali et al. (2020) reported significant positive correlations between seed yield and head diameter. There were significant positive correlations between thousand-seed weight and seed yield in the present study. Head diameter alone does not influence seed yield, but becomes significant with the number of 
heads. High seed yields are achieved with both greater number of heads and greater head diameters and head diameter alone is not significant for seed yield.

Oil content (OC) showed significant positive correlations with oil yield (OY), number of days to flowering (NDF) and number of branches (NB). While seed yields are mainly influenced by environmental conditions, plant genetics play a key role in oil content (Kaya et al., 2009). Therefore, it is not efficient to select genotypes for oil content based on morphological traits.

Oil yield (OY) had insignificant correlations with number of days to flowering (NDF) and head diameter (HD), but had significant positive correlations with the other traits (Table 5).

The crude oil yield of safflower is calculated from the crude oil ratio and seed yield values. Therefore, the factors influencing oil content and seed yield also influence oil yield. Therefore, it is possible to state that all factors influencing seed yield also influence crude oil yield (Oztürk et al., 2009).

The GT biplot graph showed two principle components (PC1 and $\mathrm{PC} 2$ ) and explained 53.6\% of total variation (PCI 29.6\% and PC2 24\%) (Figure 1). High explanation ratios are desired in GT biplot graphs since such graphs allow researchers to better and more reliably assess experimental data (Yan et al., 2007).

Provided that the biplot graph sufficiently explains total variation ( $\geq 50 \%$ ), the correlation coefficient is almost equal to the cosine of the angle between the vectors of two traits (Kroonenberg, 1995).

A correlation coefficient $(r)$ is positive when the angle between the vectors of two traits is $<90^{\circ}$, negative when the angle is $>90^{\circ}$ and independent (0) when the angle is $90^{\circ}$. The traits with longer vector lengths are more susceptible to genotype combinations; the traits with shorter vector lengths are less susceptible to genotype combinations ( $\mathrm{Rad}$ et al., 2013). According to the present biplot graph, the angle of seed yield (SY) vector with oil yield (OY), head diameter (HD), number of branches (NB), thousand-seed weight (TSW), number of heads $(\mathrm{NH})$ and plant height $(\mathrm{PH})$ vectors was $<$ 90o (Figure 1). Seed yield had significant positive correlations with these traits. The angle of seed yield (SY) vector with number of days to flowering (NDF) and oil content (OC) was about 90o (Figure 1). Therefore, seed yield had insignificant correlations with these traits $(r=\cos 90=0)$. The angle between the oil content (OC) and oil yield (OY) vectors was $<90 \mathrm{o}$ and there was a positive correlation between these traits $(r=\cos 0=+1$ and $r=\cos 60=0.5)$. The angle of oil content (OC) vector with seed yield (SY) and head diameter (HD) vectors was about $90^{\circ}$, thus the correlation coefficient was almost zero (0), indicating insignificant correlations $(r=\cos 90=0)$. The angle of oil content (OC) vector with number of days to flowering (NDF), number of heads $(\mathrm{NH})$, thousand-seed weight (TSW) and number of branches (NB) vectors was $>90$, thus oil content had negative correlations with these traits $(\mathrm{r}=\cos$ $120=-0.5$ and $r=\cos 180=-1)$. Since oil yield was calculated from seed yield and oil content values, it yielded similar outcomes with these traits. Although the biplot analysis was developed for the analysis of genotype $\mathrm{x}$ environment interactions on seed yield, such as quantitative traits, it is also used to assess the relationships between the agronomic traits of the genotype (Yan and Kang, 2003).

With regard to genotype-trait relationships, it was observed that the genotypes G5, G4, G9 and G1 were prominent for seed yield (SY); G6, G11, Linas, Balc1 and Göktürk genotypes were prominent for oil content (OC); G7, G3, G1, Göktürk, G4, G5, G9 genotypes were prominent for oil yield (OY). The genotypes Dinçer, G14 and G13 generated a difference for plant height $(\mathrm{PH})$ and the genotypes G16, G13 and G15 generated a difference for number of days to flowering (NDF). The genotypes G5, G9, G4 and G1 were superior for head diameter (HD) and the genotypes G13, G15 and G14 were superior for thousand-seed weight (TSW) over the other genotypes.

The outcomes from the biplot graph (Fig.1) and correlation table (Table 5) mostly supported each other. Slight differences were attributed to normalized values for the biplot analysis and 53.6\% rate of explanation of total variance by the biplot graph (PC1 and PC 2: 53.6\%).

Since the GGE Biplot analysis allowed visual assessment of several traits simultaneously and thus influenced the success of selection, it was considered as an innovative approach to be used in plant breeding programs (Yau, 1995; Yan et al., 2007).

\section{CONCLUSIONS}

This study is significant in that it presented the relationships between traits through both correlation 
analysis and biplot analysis. Based on the results of the two approaches, plant height $(\mathrm{PH})$, number of branches (NB), number of heads $(\mathrm{NH})$ and thousand-seed weight (TSW) were identified as the most significant selection criteria for yield in safflower. On the other hand, while there were significant positive correlations between seed yield (SY) and head diameter (HD) in the biplot graph, the relationships between these traits were not found to be significant in the correlation analysis.

Seed yield had insignificant correlations with number of days to flowering (NDF) in the biplot analysis, but significant correlations at 5\% level in the correlation analysis. Combined use of different approaches in the assessment of relationships between the traits will improve the chance for success.

The data obtained from this study could be useful for safflower breeders and safflower producers concerned with increasing seed yield. The main traits determined in this study which affected seed yield in safflower were plant height $(\mathrm{PH})$, number of branches (NB), number of heads (NH) and thousandseed weight (TSW) and this can be used as selection criteria during safflower breeding programs.

The GT biplot graph put forth the relationships among the investigated traits of the genotypes and provided significant advantages for the selection of genotypes and cultivars to be used as parent materials in breeding programs. The method also offered practical and efficient assessment of the strong and weak points of the genotypes.

\section{REFERENCES}

Akbar AA, Kamran M. 2006. Relationship among yield components and selection criteria for yield improvement in safflower (Cathamus tinctorious L.). J. Appl. Sci. 6, 2853-2855.

Akçura M. 2011. The relationships of some traits in Turkish winter bread wheat landraces. Turk. J. Agric. Forestry 35 (2), 115-125. https://doi. org/10.3923/jas.2006.2853.2855

Ali F, Yilmaz A, Chaudhary HJ, Nadeem MA, Rabbani MA, Arslan Y, Nawaz MA, Habyarımanas E, Baloch FS. 2020. Investigation of morphoagronomic performance and selection indices in the international safflower panel for breeding perspectives. Turk. J. Agric. Forestry. 44 (2), 103-120. https://doi.org/10.3906/tar1902-49
Alizadeh K. 2005. Safflower as a new crop in the cold drylands of Iran. Sesame and Safflower Newslatter 20, 92-94.

Arslan B. 2007. The path analysis of yield and its components in safflower (Carthamus tinctorius L.). J. Biologic. Sci. 7, 668-672. https://doi. org/10.3923/jbs.2007.668.672

Baljani R, Shekari F, Sabaghnia N. 2015. Biplot analysis of trait relations of some safflower (Carthamus tinctorius L.) genotypes in Iran. Crop Res. 50, 63-73.

Camas N, Cirak C, Esendal E. 2007. Seed yield, oil content and fatty composition of safflower (Carthamus tinctorius L.) grown in northern Turkey conditions. J. Agric. Fac. Ondokuz Mayls University 22, 98-104.

Coşge B, Kaya D. 2008. Performance of some safflower (Carthamus tinctorius L.) varieties sown in late-autumn and late-spring. SDU J. Nat. Appl. Sci. 12, 13-18.

Eslam BP, Monirifar H, Ghassemi MT. 2010. Evaluation of late season drought effects on seed and oil yields in spring safflower genotypes. Turk. J. Agric. Forestry 34, 373-380.

Flores F, Moreno MT, Cubero JI. 1998. A comparison of univariate and multivariate methods to analyze $\mathrm{G} \times \mathrm{E}$ interaction. Field Crops Res. 56, 271-286. https://doi.org/10.1016/S0378-4290(97)00095-6

Golkar P, Arzani A, Rezai AM. 2012. Genetic analysis of agronomic traits in safflower (Carthamus tinctorious L.). Notulae Botanicae Horti Agrobotanici Cluj-Napoca 40 (1), 276-281. https://doi.org/10.15835/nbha4017209

Hussein A, Ibrahim AE, Hussein I, Idris S. 2018. Assessment of genotype $\mathrm{x}$ environment interactions and stability for seed yield of selected safflower (Carthamus tinctorius L.) genotypes in central and northern Sudan. Gezira J. Agric. Sci. 16.

Kaya Y, Evci G, Pekcan V, Gucer T, Yilmaz Mİ. 2009. The Determination Relationships between Oil Yield and Some Yield Traits in Sunflower. $J$. Agric. Sci. 15, 310-318.

Koç H, Keles R, Ulker R, Gumuscü G, Ercan B, Akcacik AG, Gunes A, Ozdemir F, Ozer E, Uludag E. 2010. Determination of yield, yield components and quality properties of some safflower (Carthamus tinctorius L.) lines and relations between these properties. J. Crop Res. 2, 1-7. 
Kose A. 2017. Agricultural performances of some safflower (Carthamus tinctorius L.) varieties under Eskisehir vonditions. Selcuk J. Agric. Food Sci. 31, 1-7. https://doi.org/10.15316/SJAFS.2018.55

Kroonenberg PM. 1995. Introduction to biplots for G $\times$ E tables. Department of Mathematics. Research Report 51. University of Queensland, Australia. [Online] Available: http://three-mode.leidenuniv. $\mathrm{nl} /$ document/biplot.pdf.

Mozaffari K, Asadi A. 2006. Relationships among traits using correlation principal components and path analysis in safflower mutants sown in irrigated and drought stress condition. Asian J. Plant Sci. 5, 977-983. https://doi.org/10.3923/ajps.2006.977.983

Nabloussi A, Fechtali ME, Lyagoubi S. 2008. Agronomic and technological evaluation of a world safflower collection in Moroccan Conditions. VII. International Safflower Conference. Wagga -Australia.

Ozturk O, Ada R, Akinerdem F. 2009. Determination of yield and yield components of some safflower cultivars under irrigated and dry conditions. Selcuk J. Agric. Food Sci. 23,16-27.

Rad MN, Kadir MA, Rafii MY, Jaafar HZ, Naghavi MR, Ahmadi F. 2013. Genotype environment interaction by AMMI and GGE biplot analysis in three consecutive generations of wheat (Triticum aestivum) under normal and drought stress conditions. Australian J. Crop Sci. 7, 956.

Rubio J, Cubero JI, Martin LM, Suso MJ, Flores F. 2004. Biplot analysis of trait relations of white lupin in Spain. Euphytica 135, 217-224. https:// doi.org/10.1023/B:EUPH.0000014911.70355.c9

Weiss EA. 2000. Oilseed Crops. Blackwell Publishing Limited, London, UK.

Yan W, Kang MS, Manjit B, Woods CS, Corneliusd PL. 2007. GGE Biplot vs. AMMI Analysis of Genotypeby-Environment Data. Crop Sci. 47, 643653. https://doi.org/10.2135/cropsci2006.06.0374

Yan W, Kang MS. 2003. GGE biplotanalysis.Agraphical tool for breeders, geneticists and agronomists. CRC press. https://doi.org/10.1201/9781420040371

Yan W, Rajcan I. 2002. Biplot analysis of test sites and trait relations of soybean in Ontario. Crop Sci. 42, 11-20. https://doi.org/10.2135/cropsci2002.1100

Yan W, Frégeau-Reid J. 2008. Breeding line selection based on multiple traits. Crop Sci. 48, 417-423. https://doi.org/10.2135/cropsci2007.05.0254

Yan W, Tinker NA, Bekele WA, Mitchell-Fetch J, Fregeau-Reid J. 2019a. Theoretical unification and practical Integration of conventional methods and genomic selection in plant breeding. Crop breed. Genetics and Genomics 1 (2).

Yan W, Frégeau-Reid J, Mountain N, Kobler J. 2019b. Genotype and management evaluation based on genotype by yield* trait (GYT) analysis. Crop Breed Genetics and Genomics 1 (2).

Yau SK. 1995. Regression and AMMI analyses of genotype $\mathrm{x}$ environment interactions, an empirical comparison. Agronomy J. 87, 121-126. https://doi. org/10.2134/agronj1995.00021962008700010021x 